\title{
Inhibition of cortisol production by metyrapone enhances trace, but not delay, eyeblink conditioning
}

Frauke Nees • Steffen Richter •

Johanna Lass-Hennemann • Terry D. Blumenthal •

Hartmut Schächinger

Published online: 2 September 2008

(C) Springer-Verlag 2008

Erratum to: Psychopharmacology (2008) 199:183-190

\section{DOI 10.1007/s00213-008-1155-2}

The original version of this article unfortunately contained a mistake. In the Abstract, the first word should be "Hypercortisolism" and not "Hypocortisolism."

The online version of the original article can be found at http://dx.doi. org/10.1007/s00213-008-1155-2.

F. Nees $\cdot$ S. Richter $\cdot$ J. Lass-Hennemann $\cdot$ H. Schächinger $(\triangle)$ Institute of Psychobiology, University of Trier,

54290 Trier, Germany

e-mail: schaechi@uni-trier.de

T. D. Blumenthal

Department of Psychology, Wake Forest University,

Winston-Salem, NC, USA 